\title{
МАС-СПЕКТРОМЕТРИЧНИЙ АНАЛІЗ ПРОМІЖНИХ ЕЛЕМЕНТІВ ДРУКАРСЬКИХ ФОРМ ПЛОСКОГО ОФСЕТНОГО ДРУКУ
}

\author{
( В. М. Скиба, к.т.н., ст. викладач, НТУУ «КПІ», Київ, \\ Україна
}

Проведено исследование влияния процесса печати на смену составляющих гидрофильной пленки пробельного элемента монометаллических форм плоской офсетной печати с увлажнением.

Was explored impact of the printing process on change of components of hydrophilic film of the non-printing elements on the offset printing plates.

\section{Постановка проблеми}

Стабільність властивостей проміжних елементів, що були сформовані на етапах підготовки оксидної плівки та формних пластин у цілому, залежить від перебігу процесів у надтонких поверхневих шарах оксидної плівки протягом процесу друкування, а на закономірності зміни характеру перебігу цих процесів впливає як структурно-механічні властивості друкарської форми під час друку, так і параметри друкарського процесу [1-6]. Тож дослідження поверхні проміжних елементів друкарської форми плоского офсетного друку зі зволоженням дозволить не лише встановити вплив процесу друкування на поточні властивості друкарської форми, а й дозволить розкрити саму суть механізмів фізико-хімічної взаємодії елементів середовища друкарського контакту, що в свою чергу допоможе підвищити тиражну якість друкарських форм шляхом стабілізації параметрів зво- ложення протягом друкування всього накладу.

Хоча в попередній роботі [6] методом рентгеноспектрального мікроаналізу вже було встановлено вплив процесу друкування на зміну поелементного складу оксидної плівки, що характеризується зменшенням масових часток її складників та виражається у поступовій втраті проміжними елементами своїх гідрофільних властивостей. Однак, даний метод не дозволяє детально провести аналіз складу органічних сполук, які $є$ визначальними у формуванні гідрофільних властивостей проміжного елементу друкарської форми.

Саме тому надзвичайно актуальним $€$ вивчення і дослідження впливу експлуатаційного середовища процесу друкування на хімічний склад та концентрацію складників гідрофільної плівки проміжних елементів монометалевих друкарських форм, що дасть можливість визначити майбутні на- 
прямки стабілізації їх тиражної якості.

\section{Мета роботи}

Проведення дослідження впливу процесу друкування на зміну складників гідрофільної плівки проміжних елементів монометалевих друкарських форм плоского офсетного друку зі зволоженням.

\section{Результати проведених досліджень}

Дослідження температурнопрограмованої десорбціоної мас-спектрометрії проводилось на мас-спектрометрі MX-7304A (КНУ ім. Шевченко) с іонізацією електронами, удосконаленого для проведення термодесорбційних вимірювань.

Зразок ДФ площею $5 \times 5$ мм розміщується на дні кварцмолібденової ампули. Програмоване лінійне нагрівання зразку проходило із швидкістю $0,15^{\circ} \mathrm{C} \mathrm{c}^{-1}$ до температури $\sim 790^{\circ} \mathrm{C}$.

Леткі продукти термолізу, через високовакуумний вентиль діаметром 5,4 мм, потрапляють до іонізаційної камери масспектрометра, іонізуються та фрагментуються під дією електронів, після поділу на маси в мас-аналізаторі, інтенсивність іонного струму продуктів десорбції і термолізу регіструється вторинно-електронним помножувачем ВЭУ-6. Реєстрація і аналіз мас-спектрів проводиться автоматизованою системою реєстрації та обробки даних на базі ПК. Реєстрація мас-спектрів проводиться в діапазоні 1-210 а.о.м.
Отримані термограми відображають зареєстровані в приладі процеси, що призводять до виносу в газову фазу продуктів реакцій (молекулярних потоків зразка в газову фазу) протягом підігріву зразка. Площа (висота) піку слугує мірою кількості продукту хімічної реакції, що виноситься в газову фазу.

Дослідження методом температурно-програмованої десорбціоної мас-спектрометрії дозволяє отримувати кількість термокінетичних піків, що співпадає 3 кількістю десорбованих сполук [7-9].

При проведенні термодесорбційного дослідження нагрівання зразка проводилось достатньо повільно, швидкість відкачування летких продуктів термолізу була високою, тож дифузійними ефектами можна знехтувати, тому інтенсивність іонного струму була пропорційна швидкості десорбції.

На мас-спектрі проміжного елементу нової друкарської форми, що отриманий іонізацією електронів (див. рис. 1) виявлені максимуми фрагментарних іонів сполук з такими атомарними масами: $3 \mathrm{~m} / \mathrm{z} 18-$ для води $\left(\mathrm{H}_{2} \mathrm{O}\right) ; 3 \mathrm{~m} / \mathrm{z} 28$ - для сполук азоту (N); з m/z 29 - для органічних сполук кремнію (SiH); з m/z 43 - для похідних кремнію $\left(\mathrm{SiCH}_{3}\right)$ [7].

Аналіз мас-спектрометричної інформації, отриманої при термолізі зразків проміжного елементу друкарської форми, виявив наявність на поверхні та у структурі оксидної плівки фізично та хімічно адсорбовану 


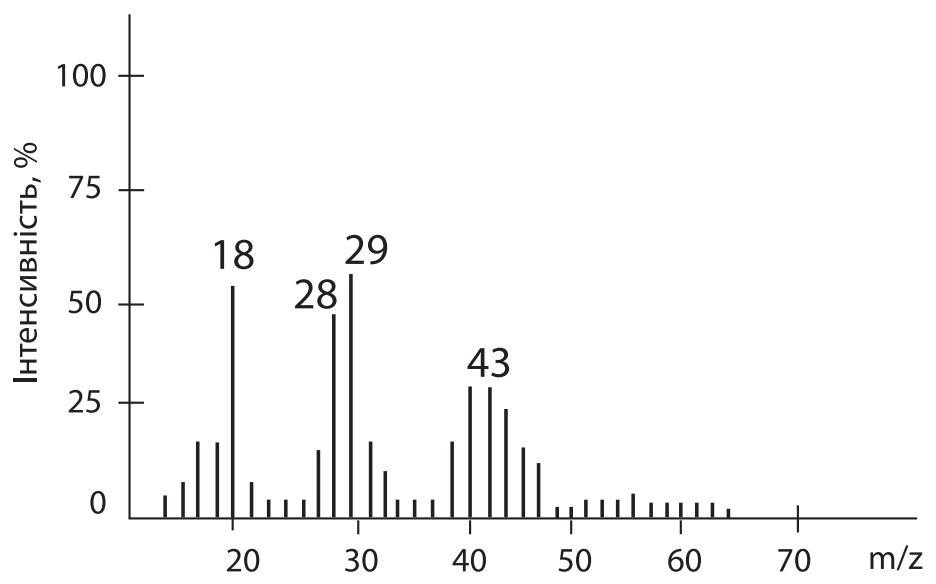

Рис. 1. Мас-спектр ПрЕ ДФ до друку

воду. Дані результати пояснюються особливостями створення оксидної плівки та формування самого проміжного елементу, а саме процесами оксидування алюмінію, утворенням гідрат окису алюмінію $\mathrm{Al}(\mathrm{OH})_{3}$ та процесами проявлення проекспонованої формної пластини [3].

Встановлені фрагментарні іони органічних сполук кремнію (SiH) та похідних кремнію $\left(\mathrm{SiCH}_{3}\right)$ можна ідентифікувати як продукти дисоціації сполук водного розчину силікату натрію та натрієвої солі карбоксиметилцелюлози, що застосовуються для наповнення оксидної плівки та дозволяє отримати на поверхні проміжного елементу стійку гідрофільну плівку.

Виявлений максимум для іону 3 масою 28 можна розглядати як сполуки азоту, що можуть бути присутніми у складі оксидної плівки, так як процес підготовки алюмінієвої основи електрохімічним зерненням протікає під дією змінного струму у азотній кислоті.
При дослідженні зразків проміжних елементів друкарських форм, що були у друкарському контакті, були виявлені максимуми фрагментарних іонів для сполук з такими атомарними масами (див. рис. 2): $3 \mathrm{~m} / \mathrm{z} 18$ - для води $\left(\mathrm{H}_{2} \mathrm{O}\right)$; $3 \mathrm{~m} / \mathrm{z} 28$ - для сполук азоту (N); $3 \mathrm{~m} / \mathrm{z} 29$ - для органічних сполук кремнію (SiH) [7].

Виявлені сполуки методом температурно-програмованої десорбціоної мас-спектрометрії при дослідженні проміжних елементів нових та спрацьованих друкарських форм підтверджуються результатами попередніх досліджень [6].

При порівнянні мас-спектрів зразків ПрЕ ДФ до та після процесу друку (див. рис. 1, 2) спостерігається загальне зменшення інтенсивності десорбованих сполук та відсутність іону 3 атомарною масою 43 для проміжних елементів після друку, що пояснюеться трибохімічним впливом експлуатаційного середовища. Отри- 


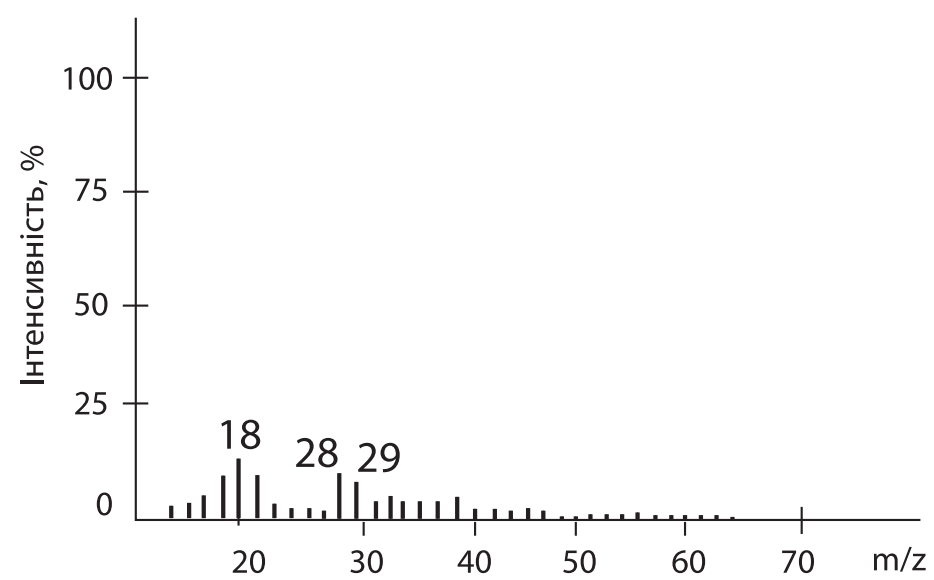

Рис. 2. Мас-спектр ПрЕ ДФ після 70,0 тис. відбитків

мані результати свідчать про суттєвий фізико-хімічний вплив експлуатаційного середовища процесу друкування на стабільність оксидної плівки проміжних елементів, що характеризуються зменшенням концентрації складників гідрофільної плівки та призводить до поступової втрати здатності змочування поверхнею проміжних елементів. В свою чергу руйнування високорозвиненої капілярної структури, під дією фізико-механічного впливу друкарського контакту, призводить до зниження капілярної підкачки порами оксидної плівки, що суттєво погіршує здатність поверхні проміжного елементу до утримування запасеного нею зволожувального розчину.

Таким чином, складники оксидної плівки, а саме гідрофілізуючі речовини, що адсорбовані поверхнею та структурою проміжного елементу в процесі експлуатації друкарської форми зазнають фізико-хімічного та фізико-ме- ханічного впливу друкарського контакту та повністю витрачаються, виконуючи свої функції лише протягом певного накладу, що призводить до поступового погіршення змочування поверхні проміжних елементів та може призвести до появи негативних процесів їх зажирення.

\section{Висновки}

1. Встановлено вплив друкарського контакту на зміну складників гідрофільної плівки проміжних елементів сучасних монометалевих друкарських форм плоского офсетного друку зі зволоженням.

2. Визначено характер процесів втрачання проміжними елементами своїх властивостей протягом процесу друкування, що характеризується поступовим зменшенням кількості гідрофілізуючих речовин оксидної плівки проміжного елементу під фізико-хімічного та фізико-механічного впливу друкарського середовища. 
3. Встановлена необхідність проведення експериментальних досліджень для встановлення оптимальних експлуатаційних умов та середовища друкарського контакту, що дозволить максимальну ідентичність відбитків у межах визначеного накладу.

1. Величко О. М. Опрацювання інформаційного потоку взаємодією елементів друкарського контакту : Монографія / Олена Михайлівна Величко К. : Видавничо-поліграфічний центр «Київський політехнік», 2005. - 264 с. 2. Зоренко О. В. Декелі в друкарському процесі [Текст] : монографія / О. В. Зоренко, О. Ф. Розум. - К. : Видавничо-поліграфічний центр «Київський університет», 2008. - 168 с. 3. Скиба В. М. Вплив підготовки поверхні пробільних елементів на їх тиражну якість / В. М. Скиба, Т. Г. Осипова // Наукові записки. - Львів : УАД, 2011. - № 3(36). - С. 298-302. 4. Трауцеддел Р. Поверхневі явища на формах офсетного друку / Р. Трауцеддел, К. Вольф // Технологія і техніка друкарства. - К. : НТУУ «КПІ» ВПІ, 2003. - № 1. - C. 42-45. 5. Velychko O. Isopropanol water based solutions in the offset printing and photooxidation processes / O. Velychko, V. Sherstyuk, O. Zorenko // Технологія і техніка друкарства. - К. : НТУУ «КПІ» ВПІ, 2003. № 2. - С. 53-58. 6. Скиба В. М. Хімічний аналіз поверхні пробільних елементів форм плоского офсетного друку методом рентгенівського мікроаналізу / В. М. Скиба, О. Ю. Коваль, О. М. Величко // Технологія і техніка друкарства. - К. : НТУУ «КПІ» ВПІ, 2010. - № 4(30). - С. 198-205. 7. Лебедев А. Т. Масс-спектрометрия в органической химии / А. Т. Лебедев. - М. : Бином, 2003. - 493 с. 8. Масс-спектрометрическое исследование кинетики и механизмов реакций алифатических карбоновых кислот на поверхности высоко-дисперсного кремнезема / Т. В. Кулик, Б. Б. Паляница, Л. Р. Азизова, [та ін.] // Масс-спектрометрия. - 2008. - № 5(2). - С. 125-132. 9. Покровский В. А. Температурно-программированная десорбционная массспектрометрия и особенности неизотермической кинетики химических реакций на поверхности дисперсных твердых тел // В кн. : Химия поверхности кремнезема / Под ред. академика НАН Украины А. А.Чуйко, Ч. 2 / А. А.Чуйко, В. А. Покровский. - Киев, 2001. - С. 79.

1. Velychko O. M. Opratsiuvannia informatsiinoho potoku vzaiemodiieiu elementiv drukarskoho kontaktu : Monohrafiia / Olena Mykhailivna Velychko. - K. : Vydavnycho-polihrafichnyi tsentr «Kyivskyi politekhnik», 2005. - 264 c. 2. Zorenko O. V. Dekeli v drukarskomu protsesi [Tekst] : monohrafiia / O. V. Zorenko, O. F. Rozum. - K. : Vydavnycho-polihrafichnyi tsentr «Kyivskyi universytet», 2008. - 168 s. 3. Skyba V. M. Vplyv pidhotovky poverkhni probilnykh elementiv na yikh tyrazhnu yakist / V. M. Skyba, T. H. Osypova // Naukovi zapysky. - Lviv : UAD, 2011. - № 3(36). - S. 298-302. 4. Trautseddel R. Poverkhnevi yavyshcha na formakh ofsetnoho druku / R. Trautseddel, K. Volf // Tekhnolohiia i tekhnika drukarstva. - K. : NTUU «KPI» VPI, 2003. - № 1. S. 42-45. 5. Velychko O. Isopropanol water based solutions in the offset printing and photooxidation processes / O. Velychko, V. Sherstyuk, O. Zorenko // Tekhnolohiia i tekhnika drukarstva. - K. : NTUU «KPI» VPI, 2003. - № 2. S. 53-58. 6. Skyba V. M. Khimichnyi analiz poverkhni probilnykh elementiv form ploskoho ofsetnoho druku metodom renthenivskoho mikroanalizu / V. M. Skyba, O. Iu. Koval, O. M. Velychko // Tekhnolohiia i tekhnika drukarstva. - K. : NTUU 
«KPI» VPI, 2010. - № 4(30). - S. 198-205. 7. Lebedev A. T. Mass-spektrometrija v organicheskoj himii / A. T. Lebedev. - M. : Binom, 2003. - $493 \mathrm{~s}$. 8. Mass-spektrometricheskoe issledovanie kinetiki i mehanizmov reakcij alifaticheskih karbonovyh kislot na poverhnosti vysoko-dispersnogo kremnezema / T. V. Kulik, B. B. Paljanica, L. R. Azizova, [ta in.] // Mass-spektrometrija. 2008. - № 5(2). - S. 125-132. 9. Pokrovskij V. A. Temperaturno-programmirovannaja desorbcionnaja mass-spektrometrija i osobennosti neizotermicheskoj kinetiki himicheskih reakcij na poverhnosti dispersnyh tverdyh tel // V kn. : Himija poverhnosti kremnezema / Pod red. akademika NAN Ukrainy A. A. Chujko, Ch. 2 / A. A. Chujko, V. A. Pokrovskij. - Kiev, 2001. - C. 79.

Рецензент - О. В. Зоренко, К.т.н., доцент, НТУУ «КПІ»

Надійшла до редакції 07.09.12 